\title{
HINDUTVA AND HINDU NATIONALISM
}

\author{
Ms. Suchithra T
}

\begin{abstract}
In Europe the concept of nationalism emerged with the rise of nation state. In states like India nationalism emerged as a result of anti-colonial movement. Nationalism is nothing but feeling of belongingness or oneness. There are different kinds of nationalism. Ethnic nationalism, Expansionist nationalism, Revolutionary Nationalism, liberal nationalism, cultural nationalism and so on. There are two major kinds of nationalism emerged in India in different points of time and how nationalism converted over a period of time. The first kind of nationalism developed du ring our freedom struggle largely under the leadership of Indian National Congress, The second one is Hindu Nationalism. This paper is discussing about how Hindutva and Hindu Nationalism developed through exponents and organizations of Hindutva ideology.
\end{abstract}

Keywords: Hindu Nationalism, Hindutva, Cultural Nationalism

\section{Introduction}

Nationalism is nothing but feeling of belongingness or oneness. In Europe the concept of nationalism emerged with the rise of nation state. In states like India nationalism emerged as a result of anti-colonial movement. There are different kinds of nationalism. Ethnic nationalism, Expansionist nationalism, Revolutionary Nationalism, liberal nationalism, cultural nationalism and so on. This paper is discussing about two major kinds of nationalism emerged in India in different points of time and how nationalism converted over a period of time. The first kind of nationalism developed in India during our freedom struggle largely under the leadership of Indian National Congress.

\section{Hindu Nationalism}

Hindu Nationalism is a cultural nationalism. We need to make distinction between political and cultural nationalism. The distinctions are not exclusive. There are cultural appropriations in all kind of nationalism. Cultural nationalism is called cultural because there is a distinct approach to culture where reference is more often on culture and cultural substance of nationalism. The nationalism which comes from the idea of Hindutva is Hindu nationalism which is cultural nationalism, while political nationalism is political and political formation of nation recognized and supported by culture. Hindu Nationalism, Hindutva is a form of cultural nationalism because Hindu Nationalism identifies nationalism defines nationalism and interprets nationalism on the basis of Hindu culture. 
Towards Excellence: An Indexed, Refereed \& Peer Reviewed Journal of Higher Education / Ms.

Suchitra T/ Page 35-39

\section{Difference between Hinduism and Hindutva}

There are many identifications of Hinduism, Hindutva is one of the identifications, Vinayak Damodar Savarkar coined the word 'Hindutva' to indicate its distinctiveness from Hinduism. Hindutva, he wrote, "was the life of the great race; it signified the religious cultural racial identity of the Hindus for him Hindutva was not a word but entire history." Independent India would be built on the foundation of the Hindutva. For Savarkar story of Independent India was to be story of the Hindu nation. Savarkar was of the idea that virtually everyone who has ancestral roots in India is a Hindu and that collectively they constitute a nation.

Theoretically Hindu nationalism begins with Aurobindo. Initially Aurobindo's political activity was confined to writing a series of articles' for a newspaper at the instance of its editor K.G Deshpande. He also began organizing young men in Bengal in order to build a revolutionary organization, which could be used for future revolutionary organization. Thus he involved himself in organizing secret societies at all levels often travelled to Bengal for the purpose. Aurobindo clearly believed in the efficacy of a violent revolution and worked towards revolutionary and insurrection.As a nationalist writing in1893 Aurobindo was acutely conscious of India's status as aslave nation. As a people Indians are weak, cowardly, selfish hypocritical and sentimental. But genuine patriotism and an authentic destiny were possible, argues Aurobindo, only through the revival of the vedic institution of the fourfold order. Chatarvarna a symbolic and typical institution often misrepresented as the four castes. By 1934 India and Hindu were interchangeable terms for Aurobindo for him nation was the mother, Durga had manifested in the form of mother. Nationalism was religion or rather religion was the only politics of the nation. Aurobindo's contribution to the political Hindutva is second to none. His ideals of Sanatana dharma and re-aryanization have been turned into political slogans. Religion indeed has become politics.

The actual foundation of Hindu nationalism was laid by V D Savankar. Savankar had very little to do with faith unlike any one before and after him Savankar politicized religion and introduced religious metaphors into politics. He pioneered an extreme, uncompromising and rhetorical from of Hindu Nationalism in Indian political discourse he wanted to establish India as a Hindu nation. He was the progenitor and most eloquent theoretician of political Hindutva. Savarkar believed in strong nation and powerful nation and power becomes centre to him. Power is not seen as a means to an end, power is an end itself so power is glorified. So his famous statement "Hinduise politics and militant Hinduism". For him Hinduism is civilization which is located both in civilization and history. Hinduism is existed from thousands of years beyond the river Sindhu. In his work "Hindutva", Savarkar defined a Hindu as one "who regards this land of Bharatavarsha, from the Indus to the Seas as his Father-Land as well as his Holy -Land that is the cradle land of his religion." He incorporated certain values of moral Hindu nation. He speaks of three cardinal values MatruBhoomi, PitruBhoomi and PunyaBhoomi. 
Towards Excellence: An Indexed, Refereed \& Peer Reviewed Journal of Higher Education / Ms.

Suchitra T/ Page 35-39

Hindutva ideology becomes strong and organized by Madhav Sadashiv Golwalkar. In his Book "We or Our Nationhood Defined" he says "From this stand point, sanctioned by the experience of shrewd old nations, the foreign races in Hindustan must either adopt the Hindu culture and language, must learn to respect Hindu religion, must entertain no idea but those of the glorification of the hindu race and culture" He was basically an organizer. As a Sarasangchalak he made the RSS a popular organization. Except North East RSS is famous in India primarily because of Golwalkar. He played a major role in the formation of Vishwa Hindu Parishad but theoretically he has not significant contribution. He had a crude version of India. In "Bunch Of thoughts" he discussed about the international enemies of Hindu culture and Indian nation. He says that first internal enemy of Hinduism and Indian nation are muslims. The second are Christians and the third are communists.

Hindu nationalism was reoriented by Deendayal Upadhyaya. He was the president of Bharathiya Jana Sangha, the forerunner of Bharathiya Janata Party. He attempted a kind of reinterpretation of varnadharma and caste system. He says varnadharma is very scientific classification of society on the basis of Guna (virtu) and Karma (practice).He said over a period of time caste system is diluted distorted and it has to be removed. Instead of birth, Guna and Dharma should become core principles of caste system and rigidity of caste system is removed and he said a scientific way of stratification needed because there is no society without social stratification and so that we make that system scientific. He is important in terms of his recognition of need of the social stratification flourishing of cultural nationalism. Hindu nationalism is champion of stratified Hindu society. Hindu nationalism has acceptance of Braminism and caste stratification. Hindu nationalism ultimately establishes Braminical hegemony.

\section{Organizational Network of Hindutva}

Hindutva is larger complex of thinkers, institutions and networking both formal and informal discourses. We cannot identify Hindutva without organizational network. The organizational network, which Hindutva has, was one of the reasons for the prominence of Hindutva politics in last 30 years. The rise of Hindu Mahasabha in the early part of 20th century and the subsequent emergence of Rastriya Swayamsevak Sangh in1925 forms the first stage of the institutional networking of the ideology. The formation of Bharathiya JanaSangh in 1954 to initiate political activism and the establishment of the Vishwa Hindu Parishad in 1964 to reach out to the North Eastern part of India and to organise Hindus worldover, signifies the second stage of institutional consolidation. The inception of Bharathiya Janatha Party (1980) and the establishment of Bajarang Dal and Hindu Yuvasena in the1990s mark the third stage of institutional evolution.

\section{Conclusion}

V D Savarkar, Golwalkar and Upadyaya were not alone in coming to terms with the question of Hindu identity. Tilak, Tagore, Gandhi and Lohia were significant voices in answering the question who is a Hindu? What separates them from the first.is that for them, it 
was possible to have multiple identities and also actively aspire towards acquiring these varied identities. It was important for them to celebrate their roots their culture and a sense of belonging to the idea of India it was essential to reach out to others in order to understand assimilate them. Self understanding was possible only when one had the ability to make place for those who are alien different and hostile by this they differed from the theorists of Hindutva.

According to T N Madan "Nationalism, the ideology of the nation-state, stands for the sense of togetherness of a people in terms of ethnic, religious, linguistic, territorial, and other unities. It is generally considered a secular (nonreligious) concept of Western origin. Religious nationalism is therefore considered inimical to the secular state. Empirical evidence reveals, however, that the relationship is complex and varies from case to case. This complexity is illustrated by the situation in South Asia where secular and religious nationalisms have long been in conflict and where both secular and religious states exist" today.

The liberal kind of nationalism emerged during our freedom struggle with the leadership of Indian Nationalism over a period of time became aggressive began to Bulldoze diversities. What might be the present and future of the Nationalism which started aggressively...? 


\section{References}

- Savarkar V D, Hindutva, Bharati Sahitya Sadan, Delhi India, 1923

- Golwalkar M S, We or Our Nationhood Defined, Bharat Prakashan, Nagpur, 1944

- Golwalkar M S, Bunch of Thoughts, SahityaSindhuPrakashana, Bengaluru, India, December 2015

- Madan T.N., "Religious Nationalism and the Secular State: Cultural Concerns" International Encyclopedia of the Social \& Behavioral Sciences, 2001, pages $13123-13127$

\section{Ms. Suchithra T \\ Asst. Professor \\ Department of Political Science \\ Dr. G. Shankar Govt. Women's First Grade College \& P.G Study Centre, Ajjarkadu, Udupi \\ Email: suchithraudupi@gmail.com}

